\title{
SIGNIFYING RELIGION IN SYMBOL: LOOKING UP THE RISE OF INDONESIAN RED CRESCENT (BSMI) IN PUBLIC LIFE
}

\author{
Ahmad Yunus \\ Islamic State Institute of Tulungagung, Indonesia \\ yunusmunfi@yahoo.co.id \\ Taufiqurrohim \\ Islamic State Institute of Tulungagung, Indonesia \\ taufiqurrohim@mail.ugm.ac.id
}

\begin{abstract}
In the beginning, the surface of BSMI problematizes the red symbol that was used by PMI because it was analyzed as a Christian symbol, feeling hesitant when used as a cross symbol in humanitarian missions is the basic reason as their appearance of religiosities in public life. Talking about the symbol, the crescent has a long history of how it can be "identified" as a symbol of Islam and how the people identified those as an identity of the religion by signifying sacred behind the symbol. The symbolization of religion cannot be separated from the method of semiotic approach where explains the science of sign. Through this sign, people can find their identity and communicate with each other as social interaction and also find a sacred behind the symbol. For the last theory, I would use the social movement and development that indicate the turn organization not only happen in the case of philanthropy but also will eradicate to the other social application movement. Therefore, in my opinion, the surface of BSMI cannot be rid by the development of crescent symbol interpretation as a symbolization of religious identity due to symbolism as a way to communicate and interact with society.
\end{abstract}

Keyword: BSMI, Crescent, identity and semiotic

\begin{abstract}
Abstrak
Pada awalnya, kemunculan BSMI adalah mempermasalahkan simbol palang merah yang digunakan oleh PMI karena dianalisis sebagai simbol Kristen, merasa ragu ketika menggunakan simbol salib dalam misi kemanusiaan adalah alasan dasar sebagai penampilan religiusitas dalam kehidupan publik. Berbicara tentang simbol, bulan sabit memiliki sejarah panjang bagaimana ia dapat "diidentifikasi" sebagai simbol Islam dan bagaimana orang mengidentifikasi hal tersebut sebagai identitas agama dengan menandakan sakral di belakang simbol. Simbolisasi agama tidak dapat dipisahkan dengan metode pendekatan semiotik di mana menjelaskan tentang ilmu tanda. Melalui tanda ini, orang dapat menemukan identitasnya dan berkomunikasi satu sama lain
\end{abstract}


sebagai interaksi sosial dan juga menemukan sakral dibalik simbol. Untuk teori terakhir, saya akan menggunakan gerakan dan pengembangan sosial yang mengindikasikan perubahan organisasi tidak hanya terjadi dalam kasus filantropi tetapi juga pada gerakan aplikasi sosial lainnya. Oleh karena itu, menurut pendapat saya, kemunculan BSMI tidak dapat dihilangkan dengan pengembangan interpretasi simbol bulan sabit sebagai simbolisasi identitas agama karena simbolisme sebagai cara untuk berkomunikasi dan berinteraksi di antara masyarakat.

Kata Kunci: BSMI, Bulan Sabit, Identitas, dan Semiotik

\section{Introduction}

This paper tries to investigate the rise of the Humanitarian Organization (BSMI) which tries to problematize the Red Cross symbol initiated as like Christian cross symbol which has been used by the more formerly Humanitarian institution (PMI). Specifically, the writer tries to beat out the ideology of the symbol as a religious symbol where the rising of the symbol is a product of human communication to sign and characterize ideas or states of mind rather than represent reality, using the power of words and images named semiotic method as an analysis of symbol. In the first part of the writing, I would like to describe how the implementation of the Red Crescent symbol by BSMI through the Development which I connected with the Symbolism and Development in public life. Then it will explicate how the symbolism of the crescent which is argued as a religious symbol of Islam by analyzing its chronological history and rule of its symbolization. The next, the writer will discuss the semiotic approach as a method to signify a symbol in order to find the reason behind the implication of symbolism. At the last discussion, the consideration of the social movement of the organization particularly does not step on the same path regarding the social phenomena that face by this religious movement as the religious piety in public life and resonance such problem of the society. 


\section{BSMI: The Implementation of Crescent Symbol in Public Life}

Indonesia has a long history in the implementation of the crescent symbol. Based on Hilman Latief, the crescent symbol has ever been used by some organizations after the independence of Indonesia as like Masyumi (Masyarakat Syuro Muslim Indonesia) and PSII (Persatuan Serikat Islam Indonesia) as their logos to symbolize Islamism. The crescent symbol not only used in some political party logos but also used in humanitarian welfare, for example, Mer-C (Medical Emergency Rescue Committee), Hilal Ahmar Indonesia, and also BSMI (Bulan Sabit Merah Indonesia) as an identity of Islamic religious symbolism (Latief 2011: 261). It was clear that the emblem of crescent has existed after independence of Indonesia until the present day. The emblem of crescent used as an identity of the community based on religious belief in a politic, social or humanitarian affair indeed.

But with the following time, the contestation humanitarian symbol between PMI and BSMI rise because the legality of symbol should be problematized. PMI assumes the implementation of Red Crescent emblem in humanitarian affairs breaks the Geneva Convention so the BSMI symbol here is considered as an "illegal" symbol based on the PMI, ICRC, and IFRC. Thus, the change of the Red Crescent symbol suggested by PMI into the other emblem. In the other hand, BSMI has a reason to defend its symbol which is no specific rule from the state to implement one symbol in humanitarian issues, legality from the Indonesian Ministry of the Law and Human Affairs (Dephumkam), and doubting the use of cross emblem as an expression of their religiosity in public life (Latief 2011: 264). It was like PMI challenging the "Islamization" of humanitarian organizations in Indonesia although it aimed at the symbol of the social affair. The contestation seems to privatize the symbol into a certain community which makes society confused in deciding the organization that could be supported in disaster and humanitarian events. 
Tomalin's writing about challenging "turn to religion" could be helpful for examining these considerations, she argues the selection of the particular issue in decision which way with the religion should be engaged or mixed with the other issues (2013: 69). In the concept "turn to religion", it can be seen the separation between religion and humanitarian affairs analysis. Where the symbol of PMI should be not indicated as a Christian symbol but it was neutral. PMI is humanitarian organization which has a neutral purpose without distinguishing ethnic, political community, race or religion indeed.

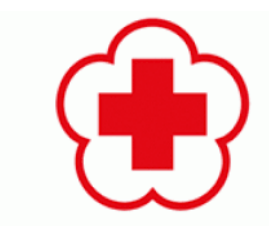

PALANG MERAH INDONESIA
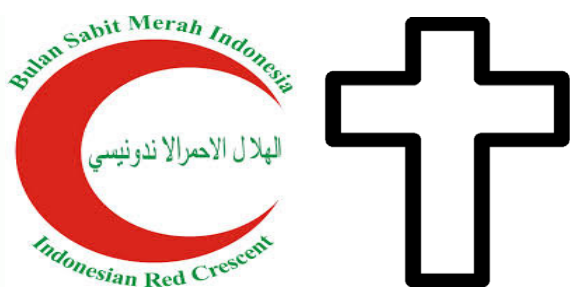

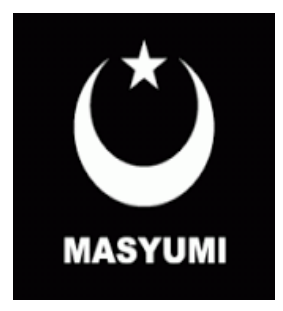

It can be seen the interpretation of PMI logo itself. Red Cross is a neutral logo for humanitarian organization who's Red Cross as an admiration of Switzerland emblem as a first host of the humanitarian conference and Henry Dunant as master mind of Humanitarian organization in 1863. Red Cross used as a sign of recognition and protection for the medical team for military victim. Red Cross on white flag used as the reverse of Switzerland emblem (http://www.pmi.or.id/ index.php/aktivitas/diseminasi/lambang.html).

It was different with the Red Crescent emblem. The Red Crescent symbol started to be used as humanitarian symbol since Ottoman Empire in 1868 and Acknowledged by ICRS since 1929. Until now, there are 33 countries that used this symbol in the state with the majority of Muslim. Indeed, Malaysia, Pakistan, and Bangladesh changed their name and emblem of humanitarian organization from Red Cross to the Red Crescent (http://bsmi.or.id/id_ID/profile/history/). 
Moreover, Benthall said that the reason behind the change of the flag is "unconscious ethnocentrism" where the flag of the Red Crescent superiority of the Christian although it has been "neutralize" by the former decision using the cross symbol as a respect of the Henry Dunant. The "infidel" feeling can be influenced their mind in using the Red Cross symbol in the humanitarian affair (Benthall 1997:159). So, feeling inferiority from the symbol that used which initiating with Christian belief, the existence of the symbol shows the superiority of the certain community because it shows their appearance and the other feeling lost from the existence so unconsciously the existed symbol attracts to the certain community centrism. It was like Counterpublics of the superiority of the existed symbolization. Counterpublics is the powerlessness respon of the human agent to acquire its ideology, material and also popularity or existence (Warner 2002: 81).

Furthermore, the change of the flag shows the feeling threaten of their religiosities. The hesitance in implying a symbol that effected to decrease of piety could be a rational reason to did not use a cross symbol. Here, I would take Suzanne Brenner's self-reconstruction and reconstruction of the society through individual and collective discipline (1996: 690). The notion to change the symbol could be come from personal perspective about the interpretation of the symbol. The other individual that find his same understanding could join and follow its ideology then it could be grow as a collective discipline that reconstruct from the personal view. The self-awareness about the piety of the use of religious symbol could be arise together with the feeling "infidelity" in implementing cross symbol based on its interpretation. When the crescent started to initiate as a religious symbol especially for Islam and why it can attract people to use its kind of the symbol as piety. The next discussion could be answered those kinds of the question. 


\section{The Development of Crescent Symbol as an Islamic Symbol}

In this stage of discussion, it could be answered why the crescent symbol is identical with a symbol of Islam. The legitimation of the symbol as a religious sign then initiated as a based belief of piety often sees from its history, compatibility of the belief, and the scriptural text as a core of the religious ideology. But sometimes, the connectivity of the religious belief and the fact behind the implication make another contradictive view rise in the surface. For that reason, the misunderstanding of religious perspective could impinge so the term of the "heresy" become a way to legitimate the other as a "wrong side".

\section{The meaning of crescent symbol in Islamic belief}

The history about the glory time of Islam in conquering Constantinople become a pride of Islamic era which symbolize by its dominance in area. It draws with the map of the authority of Islam from Constantinople until Africa so the symbolism of crescent adopted by Turk Ottoman in the west and also recognized as a Muslim flag at this fascinating era (http://muslimvoices.org/crescent-moon-islam/). The long history of Constantinople that hard to defeat becomes the last myth when Muslims can defeat those regimes in spreading their ideology in Europe through the Ottoman Turk Regime which becomes one of the Islamic glory eras excepting Mughal and Persian Muslims becoming another big time. It was like a huge pride of the Muslim a big history until drawing its map and symbolize it into the crescent. The legitimation of history becomes one of some ways to symbolize their identity in the dominance area.

The assumption of the moon as a light in the dark of the night and the cosmos. Reflection of the sun light to the moon illustrate as a witness of Islamic teaching where for Muslim, Islam bring the testimony of the God's sovereignty. So, Islam illustrated as a crescent which symbolized the relations between God and human being (Parshall 1989: 
5). The implication of the moon as Islamic identity which starting from the Muslim Calendar, hilal or counting of the praying time. Therefore, the legitimation of the moon or crescent as Islamic symbol through its history and compatibility with this religious belief but when sees about the religious ideology of symbol scripturally, there were not a "strong" argument in endorsing crescent a religious teaching so the assumption of the heretic one in using its symbol cannot be blamed.

\section{The "heretic" of crescent and star symbol}

The belief on the crescent like used an identity a religious teaching. Islam is doctrinal religion where believe in Quran, hadits and its interpretation from the expert as a basic belief of their religiosity as a good Muslim. So, the considering of the religious belief should be depended on those doctrinal view. The term "heresy" could be view on the surface when the religious belief where does not depend on the holly scriptural and hadits. The implementation of the crescent symbol could be analyzed by its source of the belief. The assumption of the Symbol of crescent as an Islamic symbol is also still debatable due to the practice of the crescent symbolization never be teach by the prophet and mentioned in the scripture. An explanation of the question of why the crescent should not be considered religious teaching because there is no scriptural text and hadith that support the implementation of the crescent in religious teaching (https://konsultasisyariah.com/23623-bulan-sabit-dan-bintanglambang-islam.html).

There were hadits mentioned about symbol of crescent for the people in community but validity and strength of the hadits is weak due to unserialized of the sanad, hadits deliverer, so it cannot be used as dalil or orientation to be religious people. In those hadits, it tells about the order of our prophet, Muhammad, for Abul Kanud to put the crescent flag for his community. Here the sanad of the hadits which unserialzed text cannot be used as a 
Sa'id bin Ufair narrated from Amr ibn Zuhair bin Amar bin Abul Kanud, that Abul Kanud ever visit to the Prophet sallallaahu 'alaihi wa sallam and flagged it.

The second is the appearance of the crescent symbol. This symbolization of the Red Crescent is because it imitates the culture of Constantinople where most of them are used in towers. The crescent illustration is a struggle for Muslims to conquer the city until dawn.

Putting crescent in a top minaret, can be categorized heresy (something new). Daula Ottoman use this symbol as the official symbol, mimics emblem on Roman palaces. Genesis the beginning that he was the father of the al-Maqduni Iskandar Akbar attacked Constantinople with his troops. In some night attack, they managed to beat the country's inhabitants and expel them. The incident coincided with the dawn of time. Then they feel optimistic with the time, and makes the image hilal (crescent) as their official emblem, to remember the event. Even this emblem is used in various castle, then imitated the descendants of the Ottomans, when they were defeated. Then it goes into country emblem Kazan. (at-Taratib al-Idariyah, al-Kittani, 1/265).

The third explanation from Ibnu Taymeen is no longer same with the second reason while the implementation of the crescent is often used in the top of the place of worshipper as a heretical belief.

About installing the new moon image in the towers, some say, that most of the Muslim that mimic other people, what they did to their places of worship. They put the crescent, to counter the Christian people who put up the symbol of the cross in their places of worship. As in the first-aid foundation for the sick as the Red Crescent, to rival owned by Christian, a red cross. Therefore, this symbol should not be placed on the towers of the mosque, given the similarity (with Christian), and considering it a waste of treasure and time. (Majmoo 'Fataawa wa Rasail Ibnu Thaymeen, 13/941).

Hadits, holly scripture, and fatwa or religious decree from the expert is a doctrinal basic teaching of the religion. When, things that are not in accordance with the basic doctrines, the contestation of religious truth 
can emerge. The dividing of the religious community will happen when the fundamentalist one tries to defend its ideologies, the conservative tries to find another way in finding psychological, ethical, and logical and humanity aspect. The consideration of humanity and psychological aspect could be rise to decide it as religious ideology by accepting its development including in symbolism. Symbolization assume as a new view to sign the environment around us. Signifying is a based concept of the human interaction and communication with the nature. Symbolization is one of the way to unify, analyze and signify the "sacred" behind its meaning of the symbol.

Therefore, Livingston argued that the symbols have the power to representing the individuals and whole society identities (2009: 55). It can be illustrated, at the first time, symbol of the crescent tells about the struggle of Muslim in conquering Constantinople but with the following, the interpretation of the symbols also developed. Hence, it cannot be blame that it is kind of the development of symbolism and its interpretation. To interpret a symbol should be used "science of sign" where sign is a customary for the human to communicate. Therefore, semiotic approach is a one of way that should be considered in analyzing religious symbol because it was not about "heresy" or not but it was about how the people communicate not only with the rationality or reality but also with the emotional meaning behind the symbol.

\section{Signifying Meaning of the Symbol through Semiotic Approach}

Talking about the chronological phase of the signing symbol, structuralism is a way how to enable meaning to emerge, especially in symbol. Ferdinand de Saussure is the influential theory of the structuralism where he makes distinction amongst 'Parole and longue' and 'signifier and signified'. Longue is the system of the language that we speak then share it unconsciously then it realized by the individual as a way of matter rationally, named Parole (Carter 2006: 42). 
Moreover, to find a sign, the process between signifier and signified should be considered. Where the signifier is basic form of the sign as like image and word, the way of think how it is referred to is signified (Turner 1998: 54).

Structuralism and semiotic cannot separated when we studied about system of the sign. Structuralism aims to the method how it can be investigated where the semiotic is the field of the study about system of the sign (Carter 2006: 43). It is C S Pierce who firstly introduced the concept of semiotic approach. Partly, interpretation mode of sign can be categorized into three types which icon, index, and especially a symbol (Jappy 2013: 80)

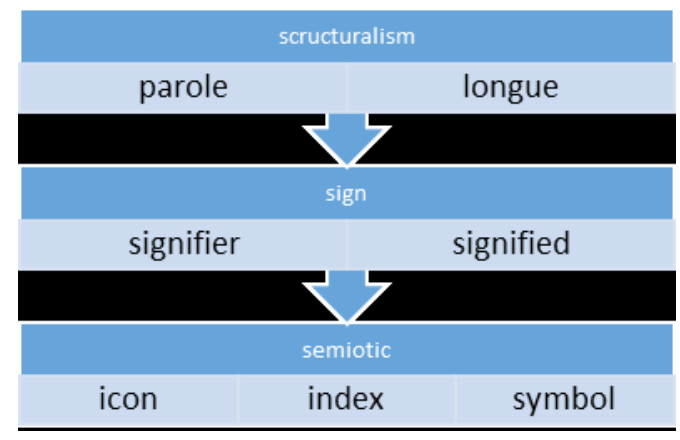

It has various definitions among icon, index, and symbol that could be distinguished. Icon is the physical resemblance of the pattern physically. It was like the picture our face is us. Differently with index, where it uses a sensory sense of visibility, hearing, smell, and touching for the example the cloud indicated could be rain and the least complicated one is a symbol. It has emotional content to sign a thing associated with the other thing but it has no relation with the intended meaning as like the word monster that could be has variated meaning in human view because influenced by human perspective (http://www.cs.indiana.edu/ port/ teach/103/sign.symbol.html). 
Therefore, the different perspectives of human interpretation with the object influencing the meaning of the symbol. The construction of human interpretation is not a problem. It could be back to the principle of the symbol itself. With the different human perspectives, it could be found different interpretations of the symbol. In the case of BSMI and PMI symbol, we see a different interpretation of the symbol, where the first time the Red Cross logo was not problematized because of its logo identically with the Switzerland national emblems. The different views could be rise because it is the "basic principles" of the symbol semiotically.

When the first time the rise of the BSMI because of problematizing a symbol, the movement of the organization was not stopped due to the problem of humanity that face the humanitarian background movement. The variety of social problem of the society necessitates the humanitarian organization to be flexible facing the urgency of the humanitarian crisis. Like in poverty, education and disaster catastrophe. Thus, for the next discussion, it is important to see how the movement of the humanitarian organization responds to the various problem of humanity, especially in this case BSMI establishment from the time to the time. Through the analytics of the website history, it can be found the organized program was applied in human problem and how the community development also happens here regarding the available space of the movement.

\section{BSMI: The Movement and Its Development}

The program that provide by BSMI is truly can be said has a large movement of the humanitarian crisis. There are nine program which are (1) Tanggap Bencana (Disaster responses), (2) Kegawat daruratan (Emergencies), (3) Pelayanan Kesehatan (Health services), (4) Kesehatan Ibu dan Anak (Mom and Kids Health services), (5) bulan Sabit Merah Remaja (Youth Red Crescent), (6) Pelayanan Ambulan (Ambulance Provider), (7) Pendidikan Kesehatan (Healthy Education), (8) Penanganan Pengungsi (Refugee Handling), (9) pemberdayaan 
Masyarakat (Community Empowerment)

From those list of community activities, it indicates that the program is widely spreading, the organization movement not merely stagnancy in the issue of the health and disaster catastrophe but it turns to be more socially engaged with the broad social issue as like community empowerment and also education.

Community development and movement also have values regarding its effect of the community development. In the report, which is published by the Center for Community Development in Scotland (Scottish Community Development Centre/SCDC), the report describes the value/positive effects of Community Development which is threedimensional. The first is community development are considered able to fight against social exclusion such as poverty and discrimination. For promoting community development has the potential to maintain social inclusion community so that the participation of citizens in addressing the issue of economic and social justice.

Second, the development community has the potential to promote "strong community" and it could be marked from full citizenship, democracy, community collaboration, and empowerment are equally without discrimination. And lastly, community development or community development could also provide public security. It can be seen from how the community can control to distinguish between private and public affairs formulated in their space. The community movement can be as control of the decentralization decision in society and the independency of the community activities. The collaboration in empowerment makes the available space for society to develop its move to the social catastrophe but it can be seen as control of stability during the social problem and human crisis. 


\section{Conclusion}

The science of sign is semiotic. The semiotician has been divided kind of sign into three categories icon, index, and symbol. Signifying symbol is a complex approach where symbol has emotional contents to interpret and sometimes it has no relation in interpretation with the symbol physically. It was like a sign of the crescent and cross where crescent was identical to Islam although it was not a symbol of Islam if we see it doctrinally. In contrast, we see the history of the crescent and compatibility assumption of the symbol, it has connectivity with religious belief.

BSMI is one of organization which has a history with the symbol contestation with PMI as the former humanitarian organization. Where BSMI problematize about the Red Cross symbol that has been used by PMI. On the other hand, PMI also problematizes the existence of the BSMI due to the "illegal" mark by ICRC, IFRC, and also PMI. The rule that permitted only choose one emblem between crescent or cross in a state become the reason illegality of the BSMI but they have a logical explanation to defend their name and emblem in a humanitarian organization which is the support from the government and the religiosity belief reason for the hesitant of using the symbol.

Therefore, to conclude this paper, I would take a Casanova's theory about the "deprivatization" of religion means to signify new historical development to a certain reversal with what appeared in secular trends to separate between religion and worldly one (Casanova 2012: 6). The existence of BSMI is the symbolic interpretation development that spread because of the converse perspective about the religious and humanitarian symbols. But it is the basic definition of the symbol where its sign uses an emotional approach to conceptualize the object.

But we say about the interpretation of the human in symbol, it is not stopped in this kind of signifying aspect. The broad movement of the 
activity would be a rise in the community as the social responsibility of the various humanitarian crisis. Hence, the development of the movement gives a positive aspect to its society as individual social empowerment in society and also control of community arrangement and representation in the public space.

\section{Bibliography}

Benthall, Jonathan. The Red Cross and Red Crescent Movement and Islamic Societies, with Special Reference to Jordan. Taylor and Francis Ltd: British Journal of Middle Eastern Studies, Vol. 24, No. 2 (Nov., 1997), pp. 157-177

Brenner, Suzanne. Reconstructing Self and Society: Javanese Muslim Women and "The Veil". Wiley on behalf of the American Anthropological Association. American Ethnologist,Vol. 23, No. 4 (Nov., 1996), pp. 673-697

Carter, David. Literary theory. Great Britain: Pocket Essential Publisher. 2006

Casanova, Jose. Public religion in modern world. Chicago: The University of Chicago, 2012

Latief, Hilman. Symbolic and ideological contestation over humanitarian emblems: the red crescent in Islamizing Indonesia. Jakarta: Studia Islamika Indonesian Journal of Islamic Studies. Vol. 18 No.2. 2011

Livingston, James C. The Anatomy of the Sacred. New Jersey: Pearson Education Ltd. 2009.

Parshall, Paul. The Cross and the Crescent: Understanding the Muslim Mind and Heart. Illionis: Tyndale House Publisher. 1989

Tomalin, Emma. Gender, Development, and the "De-privatisation" of Religion: Reframing Feminism and Religion in Asia. Palgrave McMillan published. 2013

Turner, Graeme. Film as social practice. London: Routledge. 2003 
Warner, Michael. Publics and Counterpublics. Duke University Press. Public Culture, Volume 14, Number 1, Winter 2002, pp. 49-90

\section{Online resources}

http://www.pmi.or.id/index.php/aktivitas/diseminasi/lambang.html http://bsmi.or.id/id_ID/profile/history/

http://muslimvoices.org/crescent-moon-islam/

https://konsultasisyariah.com/23623-bulan-sabit-dan-bintang-lambangislam.html

http://www.cs.indiana.edu/ port/teach/103/sign.symbol.html 
INJECT (Interdisciplinary Journal of Communication), Vol.4, No.2, Des. 2019: p. 255-270

this page intentionally left blank 